D nia 18 września 2008 r. w siedzibie Wojewódzkiej Biblioteki Publicznej - Książnicy Kopernikańskiej w Toruniu (dalej: WBP - KK) zorganizowano trzecią już edycję konferencji „Informacja regionalna w bibliotekach publicznych województwa kujawsko-pomorskiego".

Zarząd Okręgu Kujawsko-Pomorskiego Stowarzyszenia Bibliotekarzy Polskich w Toruniu oraz Sekcja Informacji Regionalnej Książnicy Kopernikańskiej (dalej: SIR) podjęły już trzy lata temu inicjatywę organizacji corocznych cyklicznych konferencji, poświęconych wymianie doświadczeń bibliotekarzy, którzy bezpośrednio zajmują się informacją regionalną. Pierwszą konferencję zorganizowano 19 września 2006 r. Uczestnicy spotkania zajęli się wówczas zagadnieniami związanymi z tworzeniem i upowszechnianiem informacji regionalnej $\mathrm{w}$ bibliotekach publicznych jako centrach informacji o regionie. Jako osobną kwestię potraktowano proces tworzenia bibliografii regionalnych w regionie kujawsko-pomorskim na tle bibliografii w Polsce. 13 września 2007 r. odbyła się kolejna edycja konferencji. Była ona odpowiedzią na pozytywne oceny, które zebrało poprzednie spotkanie regionalistów. Na drugie spotkanie materiały zostały nadesłane przez prelegentów nie tylko z Polski, ale też z zagranicy. Podczas obrad poddano analizie działalność informacyjną w bibliotekach wojewódzkich, powiatowych i miejskich, przedstawio-

\section{Konferencja „Informacja regionalna w bibliotekach publicznych województwa kujawsko-pomorskiego" (Toruń, 18 września 2008 r.)}

no także wyniki niektórych prac bibliograficznych. Dodatkowo omówiono zagadnienie współpracy bibliotek w gromadzeniu materiałów regionalnych.

III Konferencję „Informacja regionalna $\mathrm{w}$ bibliotekach publicznych województwa kujawsko-pomorskiego" otworzyła Dyrektor WBP - KK Teresa Szymorowska. Następne wystąpienie było poświęcone „Źródłom informacji regionalnej w bibliotekach publicznych województwa kujawsko-pomorskiego". Prelegenci Katarzyna Tomkowiak i Grzegorz Barecki z Sekcji Informacji Regionalnej WBP - KK omówili wyniki ankiety przeprowadzonej we wrześniu 2008 r., w której uczestniczyło 25 bibliotek z województwa kujawsko-pomorskiego. Badania miały na celu zebranie w sposób kompleksowy wiadomości o rozproszonych na terenie całego województwa źródłach informacji regionalnej, agendach zajmujących się informacją regionalną, stronach internetowych, katalogach, kartotekach, bibliografiach, starodrukach, rękopisach, kartografii, zbiorach zwartych, czasopismach, DŻS-ach. Istotne okazały się zwłaszcza informacje 
o księgozbiorach historycznych. Starodruki znajdują się w Bydgoszczy, Chełmnie, Grudziądzu i Toruniu. Publikacje zwarte i wydawnictwa ciągłe sprzed 1945 r. przechowywane są w Bydgoszczy, Chełmnie, Chełmży, GolubiuDobrzyniu, Grudziądzu, Inowrocławiu, Mogilnie, Świeciu, Toruniu, Tucholi, Wąbrzeźnie, Włocławku i Żninie. Większość bibliotek tworzy bieżącą bibliografię regionalną, publikuje własne wydawnictwa informacyjne. Poza tym biblioteki organizują szereg regionalnych imprez, takich jak spotkania z lokalnymi twórcami, wystawy, konferencje. Regionaliści wychodzą tym samym naprzeciw rosnącemu w ostatnich latach zainteresowaniu czytelników ich małymi ojczyznami.

Kolejny referat, zatytułowany „Nieznane gazety $\mathrm{z}$ terenu Pomorza do 1918/1939 r.?", wygłosił Matthias Lempart, doktorant Katedry Historii Europy Wschodniej i Południowo-Wschodniej Ludwig-Maximilians-Universität München. Autor opowiadał o swych poszukiwaniach, dzięki którym odnalazł wiele czasopism, niewymienionych nawet w Bibliografii czasopism pomorskich (Toruń-七ódź 1960), przygotowanej pod redakcją Henryka Baranowskiego. Lempart w swych badaniach korzystał m.in. z Centralnego Katalogu Czasopism Polskich i jego niemieckiego odpowiednika Zeit-schriftendatenbank. Nieocenionym źródłem okazało się jednak wydawnictwo „Preisliste der durch das Kaiserliche Post-Zeitungsamt in Berlin und die Kaiserlichen Postanstalten des Deutschen Reichs-Postgebiets im Jahre [...] zu beziehenden Zeitungen, Zeitschriften u.s.w." Był to regularnie publikowany spis tytułów czasopism wydawanych w Niemczech i poza tym krajem, których prenumeratę poczta proponowała swoim klientom.

Doktor Przemysław Olstowski z Instytutu Historii Polskiej Akademii Nauk (dalej: IH PAN) poświęcił swoje wystąpienie koncepcji programowej i znaczeniu syntezy: Historia Pomorza (t. I-IV: Poznań-Toruń 1969-2002; t. V - w przygotowaniu). Szczególne spory w nauce wywołał zasięg terytorialny pracy obejmujący ziemie od Stralsundu do Kłajpedy, a więc również terytorium dawnych Prus Wschodnich. Dzieło polskich uczonych oparte jest na bardzo gruntownych badaniach źródłowych. Obejmuje zagadnienia prawnoustrojowe, administracyjne, gospodarcze, demograficzne, społeczne, polityczne, narodowościowe, wyznaniowe, sprawy życia codziennego, kultury duchowej i materialnej, oświaty, nauki i szkolnictwa. Historię Pomorza należy uznać za syntezę wyjątkową, niemającą odpowiednika w historiografii innych dzielnic Polski ani też w historiografii europejskiej ( $w$ tym niemieckiej). Wszystko wskazuje na to, że w przeciągu najbliższych pokoleń będzie to ostatnie tego typu opracowanie zbiorowe w polskiej historiografii.

Kolejny referat, wygłoszony przez dr. Tomasza Łaszkiewicza, również z IH PAN, był poświęcony koncepcji bibliografii historii Kujaw oraz działalności oddziału Polskiego Towarzystwa Historycznego w Inowrocławiu. Bibliografia historii Kujaw rejestruje 
literaturę historyczną dotyczącą przeszłości tego regionu, daje możliwość odnalezienia $\mathrm{w}$ jednym zestawieniu książek, artykułów publikowanych w czasopismach naukowych i pracach zbiorowych oraz rzadkich, regionalnych wydawnictw niskonakładowych, nawet bez ISBN, umożliwia ogląd całości literatury historycznej poświęconej Kujawom od 2000 r., jest pomocnym narzędziem dla badaczy dziejów tego obszaru, regionalistów, studentów, młodzieży szkolnej. Bibliografia jest publikowana na łamach „Ziemi Kujawskiej", także przygotowywanej przez inowrocławskich historyków. Jest to jedyne czasopismo historyczne poświęcone dziejom całych Kujaw (wschodnich i zachodnich). Rocznik obejmuje następujące działy: artykuły, źródła i materiały, miscellanea, dyskusje i polemiki, recenzje, życie naukowe i kulturalne, bibliografia historii Kujaw, nekrologi.

Joanna Pasztaleniec-Jarzyńska z Biblioteki Narodowej w Warszawie omówiła nowe programy finansowania bibliotek publicznych. Doktor Aleksander Błachowski współpracujący ze sponsorem konferencji - Polskimi Wydawnictwami Reklamowymi, podzielił się doświadczeniami wydawcy literatury krajoznawczej w województwie kujawskopomorskim.

Bibliotekarki z bibliotek publicznych w Ciechocinku, Golubiu-Dobrzyniu i Mogilnie zaprezentowały działalność swoich placówek. Na poprzednich konferencjach prezentowały się już biblioteki z Aleksandrowa Kujawskiego, Brodnicy, Bydgoszczy, Cheł- mna, Chełmży, Grudziądza, Inowrocławia, Lipna, Radziejowa, Rypina, Sępólna Krajeńskiego, Torunia, Tucholi, Wąbrzeźna, Włocławka i Żnina.

Konferencję uwieńczyło uroczyste otwarcie wystawy medali i tablic pamiątkowych toruńskiego artysty plastyka Ryszarda Mirowskiego oraz iluminowanych inicjałów rękopiśmiennych wykonanych pod jego kierunkiem przez studentów Uniwersytetu Mikołaja Kopernika w Toruniu. Organizatorzy, podobnie jak w przypadku dwóch poprzednich spotkań, opublikowali materiały pokonferencyjne na CD-ROM-ie.

Trzy konferencje zorganizowane w siedzibie Książnicy Kopernikańskiej w Toruniu odniosły sukces, który sprawił, że planuje się organizację kolejnych takich przedsięwzięć. Wielu uczestników zgłosiło chęć ponownego wystąpienia i przedstawienia efektów swojej działalności. Także organizatorzy nie zamierzają spocząc na laurach i myślą o wyjściu z cyklem „Informacja regionalna $w$ bibliotekach publicznych województwa kujawsko-pomorskiego" poza Toruń. Dzięki współpracy z innymi ośrodkami regionalnymi idea corocznych konferencji, dających możliwość wymiany doświadczeń dotyczących informacji regionalnej, ma szansę stać się tradycją. Na 2009 r. zaplanowano organizację konferencji bibliotekarzy regionalistów przez Miejską Bibliotekę Publiczną w Tucholi.

\section{Grzegorz Barecki}

Sekcja Informacji Regionalnej, Książnica Kopernikańska w Toruniu 